\title{
Identification of Antipsychotic Side Effects with Glassgow Antipsychotic Side-Effect Scale (GASS)
}

\author{
Dita Hasni*, Vivinia Rahmi Andika Putri, Mutiara Anissa \\ Fakultas Kedokteran,Universitas Baiturrahmah,Padang, Indonesia \\ *ditahasni@fk.unbrah.ac.id \\ DOI: http://doi.org/10.29080/jhsp.v4i2.268
}

Received: November 2019, Accepted: Maret 2020, Published : Agustus 2020

\begin{tabular}{|c|c|}
\hline Keywords & Abstract \\
\hline $\begin{array}{l}\text { Schizophrenia, } \\
\text { Antipsychotics, } \\
\text { Side-effect, } \\
\text { GASS }\end{array}$ & $\begin{array}{l}\text { Schizophrenia is ranked } 4 \text { th of the top } 10 \text { diseases that burden worldwide. If the } \\
\text { population of Indonesia reaches } 200 \text { million, it estimates that around two million have } \\
\text { Schizophrenia. Based on Data from the World Health Organization (WHO), it estimates } \\
\text { that around } 24 \text { million people worldwide have schizophrenia. The American Psychiatric } \\
\text { Association (APA) were reported the incidence of Schizophrenia in the United States is } \\
\text { about } 1 \% \text { of the adult population with a total of more than } 2 \text { million people. } \\
\text { Schizophrenic patients were treated by antipsychotic agents that act to inhibit dopamine } \\
\text { receptors, especially D2, and also inhibit adrenergic acetylcholine receptors and serotonin } \\
5 \text {-HT2A. It can manifest side effects like extrapyramidal syndrome, amenorrhea, } \\
\text { drowsiness, and others. This research aims to the identification of antipsychotic side effects } \\
\text { with Glasgow Antipsychotic Side-effect Scale (GASS). } 100 \text { schizophrenics in Prof. HB } \\
\text { Saanin Mental Hospital were participating in this descriptive study after fulfilling the } \\
\text { criteria of inclusion and exclusion. This study used the GASS questionnaire to interview } \\
\text { subjects who were signing informed consent and get an explanation about this study. In } \\
\text { this study, 92\% of subjects reported mild side effects. The frequent complaints were } \\
\text { extrapyramidal effects, sedation and CNS effects, anticholinergic effects, and weight gain } \\
\text { (93\%, } 80 \%, 71 \% \text { and } 70 \% \text { respectively). We found women complained of the side effects } \\
\text { more often (16,38 } \pm 5,275) \text { than men (12,58 } \pm 5,484) \text { significantly with the value P = } \\
\text { 0,001. GASS instruments can use screening antipsychotic side effects. This study concludes } \\
\text { the most side effects complaints being extrapyramidal and drowsiness, and women more } \\
\text { commonly found side effects than men. }\end{array}$ \\
\hline
\end{tabular}

\section{Introduction}

Schizophrenia is a psychosis, a mental disorder characterized by abnormal thoughts, hallucinations, delusions (false beliefs), and disruptive work, and social functioning (1). World Health Organization (WHO) estimates that Schizophrenia affects 20 million people worldwide. It ranks 4 out of 10 major diseases that charge around the world This mental disorder is associated with disability and interfere in educational and occupational performance (2).

Prevalence of Schizophrenia in the United States, about $1 \%$ of the adult population with a total sum of more than 2 million people (3). According to the Ministry of Health of the Republic of Indonesia in 2018, about 2 million Indonesians suffered Schizophrenia, with a prevalence of $0,7 \%$ and the age of sufferers for more than 15 years. If the population of Indonesia is about 200 million, it estimates that about 1,4 million people were suffering Schizophrenia. The national Data on Basic Health Research in 2018 mentions the prevalence of the highest Schizophrenia found in Bali (1,1\%), DIY Yogya (1\%), NTB (1\%), Aceh (0,9\%), and West Sumatera (0,9\%) (4). Based on a survey of medical record data at Prof. HB. Saanin Mental Hospital, Padang said the number of patients with medication in the year 2011 was 23,870 outpatient, 9,483 $(39,73 \%)$ Among them are schizophrenia patients and from 1,573 inpatient patients, $812(51,62 \%)$ among them are schizophrenia patients.

Schizophrenia patients got treatment with antipsychotic drugs. These drugs consist of the typical antipsychotic called by the antipsychotic one generation, and atypical antipsychotics called the secondgeneration antipsychotics. Typical antipsychotic drugs work inhibiting the dopamine receptor, mainly D2, 
and also inhibit the muscarinic adrenergic acetylcholine receptors and serotonin 5-HT2A. Both are atypical antipsychotics, working by inhibiting the receptor, i.e., serotonin 5-HT2a and dopamine, although inhibition on 5-HT2A receptors is more potent than the receptor dopamine (5). These drugs are indicated for the treatment of psychotic sufferers or other severe psychiatric diseases characterized by agitation and mental disorder. Reserpine and Chlorpromazine are the first drugs that are useful for Schizophrenia (6).

These drugs can cause adverse reactions since the patient has a subjective or objective complaint due to the use of a drug at a standard dose. The effect can interfere with the quality of life schizophrenic patients and adherence to consuming drugs. Therefore, this research aims to identify complaints of side effects experienced by schizophrenic patients in Prof. HB. Saanin Menal Hospital, Padang receiving antipsychotic therapy using the Glasgow antipsychotic Side effect Scale (GASS) Questionnaire.

\section{Methods \\ Ethical approval}

This research has been approved by the Faculty of Medicine ethics of Baiturrahmah University. The number of Ethic Approval was 047/etik-fkunbrah/03/07/2018. Each participating study subject has signed an informed Consent after reading the research sheet and understanding the explanation given by the researcher.

\section{Research subject and procedure.}

One hundred schizophrenic patients were involved in this descriptive study. The subjects were signing informed consent after got an explanation about this research. This research had inclusion and exclusion criteria. The inclusion criteria were a person with Schizophrenia who was diagnosed by a psychiatrist based on DSM IV, the patient got treatment for a minimum of 12 weeks, and a person who willing to participate in research. The exclusion criteria were a person with Schizophrenia in an aggressive condition and is not cooperative. This research was conduct in Prof. HB. Saanin Mental Hospital, Padang after obtaining permission commission of the medical Faculty of Baiturrahmah University. Research subjects are recruited based on a large number of minimal samples using formula

$$
\begin{aligned}
n & =\frac{Z \alpha^{2} P Q}{d^{2}} \\
Z \alpha & =\text { raw deviation alpha type I error set at } 5 \% \text {, two-way hypothesis, so Z } \alpha=1,96 . \\
\mathrm{P} & =\text { Proportions/Proportion of side effects in patients at } 42 \% \text { (based on the manifestation } \\
\mathrm{Q} & =1-\mathrm{P} \\
& =1-0,42 \\
& =0,58 \\
\mathrm{~d} & =\text { Precision/acceptable prediction Error } 10 \%
\end{aligned}
$$

By entering the above values in the formula, obtained, we got $n=93$ samples, so the minimum number of samples studied was 93.

All participants were interviewed by the data-maker team, who had been trained by a psychiatrist. Interviews using the Glasgow Antipsychotic Side-effect Scale (GASS) questionnaire (8).

\section{Instruments}

All participants have filled in two forms, a demographic form that contains the name, age, education, marital status, diagnosis, and form of the Indonesian version of GASS. The GASS has been translated into bahasa by a certified translator.

The study uses a GASS version consisting of 22 questions. For any questions side effects of antipsychotic drugs, patients are asked to answer based on what they experienced a week ago ( 0 -Never, 1 once, 2-a few times, 3-every day). The total score is categorized into 0-21 absent or mild side effects, 22-42 moderate, and 43-63 severe side effects (8).

The actual question assesses side effects on some organ systems, i.e., Q1-2 for sedation and CNS side effects, Q3-4 for cardiovascular side effects, P5-10 for extrapyramidal side effects, Q11-13 for anticholinergic side effects, Q14 for gastrointestinal side effects, Q15 for the genitourinary side effects, Q16 for DM screening, Q17-21 prolactinaemic side effects, Q22 for weight gain.

\section{Statistical analysis.}

Data distribution normality was analyzed using the Kolmogorov-Smirnov test. Categoric data was presented in frequency and percentage. Comparison of the average value between groups using unpaired T-test and Anova Test.

\section{Results}

\section{Demographic characteristics}

One hundred people of research subjects who participated in this study have fulfilled the criteria of inclusion and exclusion and complete filling of the questionnaire. Participants consisted of 60 men and 
40 women aged $19-82$ years. (Average: $37,25, \mathrm{SD}=12,71$ ), the majority not working and unmarried. The demographic characteristics of the research subject are in the table below:

Table 1. Demographic characteristics of research subjects

\begin{tabular}{|c|c|c|}
\hline & $\mathbf{N}$ & $\%$ \\
\hline \multicolumn{3}{|l|}{ Sex } \\
\hline Male & 60 & 60,0 \\
\hline Female & 40 & 40,0 \\
\hline Age (mean \pm SD) & 37,25 & 12,714 \\
\hline \multicolumn{3}{|l|}{ Employment Status } \\
\hline Employed & 46 & 46,0 \\
\hline Unemployed & 54 & 54,0 \\
\hline \multicolumn{3}{|l|}{ Mariage } \\
\hline Single & 54 & 54,0 \\
\hline Maried & 40 & 40,0 \\
\hline Divorce & 6 & 6,0 \\
\hline Total & 100 & 100,0 \\
\hline
\end{tabular}

\section{Side effects}

In this research the most commonly encountered side effects are: "I felt sleepy during the day" (71\%), "I have been gaining weight" (70\%)," My mouth has been dry" (57\%)," I have been very thirsty and/or passing urine frequently" (57\%) and "My movements or walking have been slower up than usual" $(55 \%)$. Absent or mild side effects found in 92 patients (92\%), and eight people experienced moderate side effects $(8,0 \%)$.

Based on the organ systems involved. In this research, reported side effects are often found to be extrapyramidal side effects of $93 \%$, sedation, and CNS side effect of $80 \%$ as well as weight gain side effects of $71 \%$.

Women complained of the side effects more often $(16,38 \pm 5,275)$ than men $(12,58 \pm 5,484)$ significantly with the value $P=0,001$. Subjects that do not also work more often complain of side effects $(15,41 \pm 5,141)$ compared to the working subject $(12,57 \pm 5,969)$. There is no difference in the total score of side effects in single patients $(13,52 \pm 5,592)$, married $(14,68 \pm 5,989)$ or divorced $(14,10 \pm 5,690)$.

Table 2. GASS scale scores

\begin{tabular}{llllll}
\hline & N & Minimum & Maximum & Mean & Std. Deviation \\
\hline Total Score & 100 & 2 & 35 & 14,10 & 5,690 \\
\hline
\end{tabular}

Table 3 and Table 4 can be seen in the appendix.

In the research gained results, complaints of side effects that often arise in antipsychotic users are sedation or drowsiness, extrapyramidal side effects, and increased weight with percentages respectively $80 \%, 93 \%$, and $70 \%$ - shown in table 4 .

Table 5.Difference between demographic variables and GASS score

\begin{tabular}{lcc}
\hline & Mean \pm SD & P-value \\
\hline Sex & & \\
Male & $12,58 \pm 5,484$ & 0,001 \\
Female & $16,38 \pm 5,275$ & \\
Employment status & & 0,012 \\
Unemployed & $15,41 \pm 5,141$ & \\
Employed & $12,57 \pm 5,969$ & \\
Married Status & & 0,517 \\
Single & $13,52 \pm 5,592$ & \\
Married & $14,68 \pm 5,989$ & \\
Divorce & $14,10 \pm 5,690$ & \\
\hline
\end{tabular}

\section{Discussion}

In this study, the study subject was recruited the majority of males with an average age of $37,25 \pm$ 12,714 , with the majority employment status not working and the most unmarried like the results of this study following the existing theory that the majority of Schizophrenia are men, unmarried and yet to work. This phenomenon occurs because this mental disorder causes the sufferer to struggle to obtain a job and to run a marriage either as a result of his illness or a negative "stigma" obtained due to mental illness $\mathrm{He}$ suffered $(2,9,10)$.

In this study found $92 \%$ of research subjects no or mild side-effects, and $8 \%$ moderate. It is slightly different from the study that the Serbian who reported $64,2 \%$ of his research subjects experienced no or mild side effects, $31,6 \%$ moderate, and $4,2 \%$ severe side effects. This difference may be due to the overall subject of this study is outpatient, while the revisited research is an outpatient and hospitalization. Schizophrenic people who got therapy in outpatient got administration the drug via oral and the 
hospitalization patient taking medicine via intravenous. The difference administration of these drugs can affect the severity of side effects. Furthermore, Patients with Schizophrenia who have treated outpatient are usually relatively more stable than inpatients and are more aware of his treatment side effects.

The most side effects complained of patients is the extrapyramidal side effects of $93 \%$, consisting of complaints of muscle twitches, hand tremor, drooling. The leg had felt restless, walking slower than usual and can not control movement in the face or body amounting to $53 \%, 39 \%, 42,8 \%, 55 \%$, and $21 \%$. These findings were higher than previous studies that reported the incidence of extrapyramidal side effects by $41,1 \%$ in Serbia. This phenomenon caused the entire subject research only gets clozapine (11).

The blockade of the dopamine D2 receptor is the primary mechanism of antipsychotic treatment. Inhibition of these receptors in the mesolimbic system area will provide psychological effects and correct performance disorders. The dopamine D2 receptors are also found in the area of the region, the Basal Ganglia, which plays a role in motor movements. The blockade of D2 receptors in this area will cause extrapyramidal disorders such as Parkinsonism, Dyskinesia, tardive dyskinesia, etc $(5,12)$.

His other complaints are quite often drowsiness of $71 \%$, and his $43 \%$ feel sleepy every day. Sedation is a side effect that is often the reason for the end of the drug in schizophrenia patients (Legge et al., 2016). This complaint belongs to the category of sedation and CNS side effects. The research was reported at $80 \%$. This drowsiness arises from the blockade of histamine receptors due to the use of antipsychotic drugs (13).

In addition to feeling sleepy, complaints often feel thirsty or frequent urination is one of the complaints that often found in this research (more than 50\%). Often feeling thirsty and urination at this research is slightly lower than the research of Ignjatović Ristić et al., 2018. 57\% vs. $62 \%$. Complaints often feel thirsty, and urination on this research becomes essential to evaluate patients against diabetes mellitus. It is necessary to watch out because this typical or atypical antipsychotic drug works primarily on inhibition of dopamine D2 and D3 receptors. These receptors are also found in the cell $\beta$ pancreas and have a role in glucose regulation to inhibit the release of insulin. Inhibition of these receptors by antipsychotic drugs will increase the release of insulin. If it occurs chronically, it will cause insulin resistance similar to hyperinsulinemia in the condition of Diabetes mellitus type $2(14,15)$.

Another complaint that is often reported in this research is dry mouth (more than 50\%). Dry mouth is one of the symptoms of the anticholinergic effects occurring due to the inhibition of muscarinic receptors on the use of antipsychotics. (Lally \& MacCabe, 2015) In this study reported complaints of anticholinergic side effects amounted to $70 \%$, with details of blurred eyes $40 \%$, dry mouth $57 \%$, and urine retention 15\%). The findings were not much different from the prior research that reported a dry mouth complaint of $52,6 \%$ and a blurred vision of $43,2 \%$ (16).

Complaints of a weight gain are also quite often found in this study by $70 \%$; this complaint is slightly higher than its research of $42 \%$. This complaint is associated with a leptin signaling mechanism that is interrupted due to the use of antipsychotics. This phenomenon results in an increase in appetite in patients who get antipsychotics, which tends to weight gain $(14,17)$.

This study reported that female patients more often reported side effects than male patients. This is because women tend to be more often overdose than men. After all, the pharmacokinetics of women has a smaller distribution volume, higher free drug fraction, and a slower elimination process. This mechanism will result in higher plasma levels of the drug in women than men $(18,19)$.

This study also reported that patients who did not have a job tend to report more often side effects than patients who worked. This phenomenon is due to patients who are not working tend to be more concerned about his body condition to the side effects he suffered because his daily activities are not distracted by doing the work.

\section{Conclusion}

This research concludes that Gass instruments can use screening antipsychotic side effects, and The commonly reported side effects in this study are the mild effects, and most complaints are extrapyramidal effects, sedation, and weight gain effects.

\section{Acknowledgments}

The research team would like to thank HB Saanin Mental Hospital, Padang, which has given permission to collect data related to Schizophrenia patients.

\section{References}

1. Lally J, MacCabe JH. Antipsychotic medication in schizophrenia: a review. British Medical Bulletin. 2015 Jun;114(1):169-79.

2. Zahnia S, Wulan Sumekar D. Kajian Epidemiologis Skizofrenia. Majority. 2016;5(5):160-6. 
3. Janoutová J, Janáčková P, Šerý O, Zeman T, Ambroz P, Kovalová M, et al. Epidemiology and risk factors of Schizophrenia. Vol. 37, Neuroendocrinology Letters. Maghira and Maas Publications; 2016. p. 1-8.

4. $\quad$ Riskesdas. Riset Kesehatan Dasar 2018. Kementrian Kesehatan Republik Indonesia. 2018;

5. Chue P, Agyapong V, Abba-Aji A. Antipsychotic Drugs. In: Side Effects of Drugs Annual. 2018. p. 99119.

6. Meltzer HY. Update on Typical and Atypical Antipsychotic Drugs. Annual Review of Medicine. 2013;64(1):393-406.

7. Subramaniam S, Putu N, Sasmita S, Bagus C, Lesmana J. Prevalensi efek samping farmakoterapi terhadap penderita skizofrenia di Rumah Sakit Jiwa Bangli, Propinsi Bali. E-JURNAL MEDIKA UDAYANA. 2018;7(1):22-7.

8. Waddell L, Taylor M. A new self-rating scale for detecting atypical or second-generation antipsychotic side effects. Journal of Psychopharmacology. 2008;22(3):238-43.

9. Kamil H, Jannah SR, Tahlil T. Stigma Keluarga terhadap Penderita Skizofrenia Ditinjau dari Aspek Sosial Budaya dengan Pendekatan Sunrise Model. Prosiding Seminar Nasional Pascasarjana (SNP) Unsyiah. 2017;121-8.

10. S S, Komariah M, Karlin W. Persepsi Keluarga terhadap Skizofrenia. Jurnal Keperawatan Padjadjaran. 2014;v2(n2):124-32.

11. Ignjatović Ristić D, Cohen D, Obradović A, Nikić-Đuričić K, Drašković M, Hinić D. The Glasgow antipsychotic side-effects scale for clozapine in inpatients and outpatients with schizophrenia or schizoaffective disorder. Nordic Journal of Psychiatry. 2018;72(2):124-9.

12. Dania H, Faridah IN, Rahmah KF, Abdulah R, Barliana MI, Perwitasari DA. Hubungan Pemberian Terapi Antipsikotik terhadap Kejadian Efek Samping Sindrom Ekstrapiramidal pada Pasien Rawat Jalan di Salah Satu Rumah Sakit di Bantul, Yogyakarta. Indonesian Journal of Clinical Pharmacy. 2019;8(1).

13. Katzung B, Trevor A. Katzung's Basic \& Clinical Pharmacology. Basic and clinical Pharmacology. 2015.

14. Whicher CA, Price HC, Holt RIG. Antipsychotic medication and type 2 diabetes and impaired glucose regulation. European Journal of Endocrinology. 2018;178(6):R245-58.

15. Siafis S, Tzachanis D, Samara M, Papazisis G. Antipsychotic Drugs: From Receptor-binding Profiles to Metabolic Side Effects. Current Neuropharmacology. 2017;16(8):1210-23.

16. Ignjatović Ristić D, Cohen D, Obradović A, Nikić-Đuričić K, Drašković M, Hinić D. The Glasgow antipsychotic side-effects scale for clozapine in inpatients and outpatients with schizophrenia or schizoaffective disorder. Nordic Journal of Psychiatry. 2018;72(2):124-9.

17. Panariello F, Polsinelli G, Borlido C, Monda M, De Luca V. The role of leptin in antipsychotic-induced weight gain: Genetic and non-genetic factors. Vol. 2012, Journal of Obesity. Hindawi Publishing Corporation; 2012.

18. Soldin OP, Mattison DR. Sex differences in pharmacokinetics and pharmacodynamics. Vol. 48, Clinical Pharmacokinetics. 2009. p. 143-57.

19. Anderson SG, Livingston M, Couchman L, Smith DJ, Connolly M, Miller J, et al. Sex differences in plasma clozapine and norclozapine concentrations in clinical practice and in relation to body mass index and plasma glucose concentrations: A retrospective survey. Annals of General Psychiatry. 2015 Nov $14 ; 14(1)$. 


\section{Appendix}

Table 3. Most Common Side Effect

\begin{tabular}{|c|c|c|c|c|c|c|}
\hline No & Side effect & $\begin{array}{l}\text { Never } \\
\text { n (\%) }\end{array}$ & $\begin{array}{l}\text { once } \\
\text { n (\%) }\end{array}$ & $\begin{array}{l}\text { A few } \\
\text { times } \\
\text { n (\%) } \\
\end{array}$ & $\begin{array}{l}\text { everyday } \\
\text { n (\%) }\end{array}$ & $\begin{array}{l}\text { Total of } \\
\text { complaint } \\
\text { n (\%) }\end{array}$ \\
\hline 1 & I felt sleepy during the day & $29(29,0)$ & $8(8,0)$ & $20(20,0)$ & $43(43,0)$ & $71(71,0)$ \\
\hline 2 & I felt drugged or like a zombie & $82(82,0)$ & $12(12,0)$ & $5(5,0)$ & $1(1,0)$ & $18(18,0)$ \\
\hline 3 & $\begin{array}{l}\text { I felt dizzy when I stood up and/or } \\
\text { have fainted }\end{array}$ & $79(79,0)$ & $13(13,0)$ & $7(7,0)$ & $1(1,0)$ & $21(21,0)$ \\
\hline 4 & $\begin{array}{l}\text { I have felt my heart beating } \\
\text { irregularly or unusually fast }\end{array}$ & $68(68,0)$ & $20(20,0)$ & $11(11,0)$ & $1(1,0)$ & $32(32,0)$ \\
\hline 5 & $\begin{array}{l}\text { My muscles have been tense or } \\
\text { jerky }\end{array}$ & $47(47,0)$ & $22(22,0)$ & $28(28,0)$ & $3(3,0)$ & $53(53,0)$ \\
\hline 6 & My hands or arms have been shaky & $61(61,0)$ & $19(19,0)$ & $15(15,0)$ & $5(5,0)$ & $39(39,0)$ \\
\hline 7 & $\begin{array}{l}\text { My legs have felt restless and/or I } \\
\text { couldn't sit still }\end{array}$ & $58(58,0)$ & $17(17,0)$ & $14(14,0)$ & $11(11,0)$ & $42(42,0)$ \\
\hline 8 & I have been drooling & $92(92,0)$ & $3(3,0)$ & $3(3,0)$ & $2(2,0)$ & $8(8,0)$ \\
\hline 9 & $\begin{array}{l}\text { My movements or walking have } \\
\text { been slower than usual }\end{array}$ & $45(45,0)$ & $20(20,0)$ & $18(18,0)$ & $17(17,0)$ & $55(55,0)$ \\
\hline 10 & $\begin{array}{l}\text { I have had uncontrollable } \\
\text { movements of my face or body }\end{array}$ & $79(79,0)$ & $7(7,0)$ & $11(11,0)$ & $3(3,0)$ & $21(21,0)$ \\
\hline 11 & My vision has been blurry & $60(60,0)$ & $13(13,0)$ & $11(11,0)$ & $16(16,0)$ & $40(40,0)$ \\
\hline 12 & My mouth has been dry & $43(43,0)$ & $26(26,0)$ & $20(20,0)$ & $11(11,0)$ & $57(57,0)$ \\
\hline 13 & I have had difficulty passing urine & $85(85,0)$ & $5(5,0)$ & $8(8,0)$ & $2(2,0)$ & $15(15,0)$ \\
\hline 14 & $\begin{array}{l}\text { I have felt like I am going to be sick } \\
\text { or have vomited }\end{array}$ & $88(88,0)$ & $4(4,0)$ & $6(6,0)$ & $2(2,0)$ & $12(12,0)$ \\
\hline 15 & I have wet the bed & $95(95,0)$ & $3(3,0)$ & $2(2,0)$ & 0 & $5(5,0)$ \\
\hline 16 & $\begin{array}{l}\text { I have been very thirsty and/or } \\
\text { passing urine frequently }\end{array}$ & $43(43,0)$ & $6(6,0)$ & $28(28,0)$ & $23(23,0)$ & $57(57,0)$ \\
\hline 17 & $\begin{array}{l}\text { The areas around my nipples have } \\
\text { been sore and swollen }\end{array}$ & $84(84,0)$ & $4(4,0)$ & $9(9,0)$ & $3(3,0)$ & $16(16,0)$ \\
\hline 18 & $\begin{array}{l}\text { I have noticed fluid coming from my } \\
\text { nipples }\end{array}$ & $97(97,0)$ & $1(1,0)$ & $2(2,0)$ & 0 & $3(3,0)$ \\
\hline 19 & I have had problems enjoying sex & $81(81,0)$ & $11(11,0)$ & $8(8,0)$ & 0 & $19(19,0)$ \\
\hline 20 & $\begin{array}{l}\text { Men only: I have had problems } \\
\text { getting an erection }\end{array}$ & $39(65,0)$ & $18(30 \%)$ & $3(5,0)$ & 0 & $21(35,0)$ \\
\hline & Tick yes or no for the last three & No & \multicolumn{2}{|c|}{ Yes } & \multirow{2}{*}{\multicolumn{2}{|c|}{ Total of complaint }} \\
\hline & & $\mathrm{n}(\%)$ & \multicolumn{2}{|c|}{$\mathrm{n}(\%)$} & & \\
\hline 21 & $\begin{array}{l}\text { Women only: I have noticed a change } \\
\text { in my periods }\end{array}$ & $14(35,0)$ & & $(65,0)$ & \multicolumn{2}{|c|}{$\mathrm{n}(\%)$} \\
\hline 22 & $\begin{array}{l}\text { Men and women: I have been gaining } \\
\text { weight }\end{array}$ & $30(30,0)$ & \multicolumn{2}{|c|}{$70(70,0)$} & \multicolumn{2}{|c|}{$70(70,0)$} \\
\hline
\end{tabular}


Tabel 4. Adverse Effect of Antipsychotics based on Organ System

\begin{tabular}{lll}
\hline & $\mathbf{N}$ & $\mathbf{\%}$ \\
\hline Sedation and CNS side effects & 80 & \\
Yes & 20 & 80,0 \\
No & & 20,0 \\
Cardiovascular side effects & 46 & 46,0 \\
Yes & 54 & 54,0 \\
No & & \\
Extrapyramidal side effects & 93 & 93,0 \\
Yes & 7 & 7,0 \\
No & & 70,0 \\
Anticholinergic side effects & 70 & 30,0 \\
Yes & 30 & 12,0 \\
No & & 88,0 \\
Gastrointestinal side effects & 12 & 6,0 \\
Yes & 88 & 94,0 \\
No & & \\
Genitourinary side effect & 6 & 59,0 \\
Yes & 94 & 41,0 \\
No & & 70,0 \\
Prolactinaemic side effects & 59 & 30,0 \\
Yes & 41 & 100,0 \\
No & & \\
Weight gain side effects & 70 & 30 \\
Yes & 100 & \\
No & & \\
Total & & \\
\hline
\end{tabular}

